\title{
Correction to: Ecosystem sulfur accumulation following woody encroachment drives a more open S-cycle in a Subtropical Savanna
}

Yong Zhou $(\mathbb{D} \cdot$ Ayumi Hyodo $\mathbb{D} \cdot$ Thomas W. Boutton $\mathbb{D}$

Published online: 21 July 2021

(C) Springer Nature Switzerland AG 2021

\section{Correction to: Biogeochemistry}

https://doi.org/10.1007/s10533-021-

00829-0

In the original version the name of the second author was misspelled. The correct name is Ayumi Hyodo.

The original article has been corrected.
Publisher's Note Springer Nature remains neutral with regard to jurisdictional claims in published maps and institutional affiliations.

The original article can be found online at https:// doi.org/10.1007/s10533-021-00829-0.

Y. Zhou · A. Hyodo · T. W. Boutton $(\square)$

Department of Ecology and Conservation Biology, Texas

A\&M University, College Station, TX 77843, USA

e-mail: boutton@tamu.edu

Present Address:

Y. Zhou

Department of Ecology and Evolutionary Biology, Yale

University, New Haven, CT 06511, USA 